\title{
Documents, Processes, Transactions: the European Digital Archival (R)Evolution
}

MARTA GAIA CASTELLAN, DR.

Senior Digital Archivist, InfoCert, Qualified Trust Service Provider e-mail: marta.castellan@infocert.it

IGOR MARCOLONGO, DR.

Head of Process \& Compliance Consulting, InfoCert, Qualified Trust Service Provider e-mail: igor.marcolongo@infocert.it

Documents, Processes, Transactions: the European Digital Archival (R)Evolution

\section{ABSTRACT}

In Europe the Digital Archival Science is evolving, with regard to the 'objects' that we need to preserve (image-copies of the original documents, born-digital documents, video, data transactions), and with regard to tools and trusted services, regulated by EU laws (electronic signatures, seals, time stamps). However, we don't have a pan-european Regulation for long-term preservation, and each Member State disciplines this service with a national rule. Italy and Slovenia have an excellent Services Accreditation procedure, based on regular audit performed respectively by Agenzia per l'Italia Digitale and Arhiv Republike Slovenije, that attest a high-level of quality and security, presence of qualified staff, trust service provider reliability and compliance with norms and standards.

Documenti, processi, transazioni: la R-evoluzione archivistica digitale europea

\section{SINTESI}

In Europa la scienza archivistica sta evolvendo fortemente, sia in relazione agli 'oggetti' che necessitano di essere conservati (copie per immagini di documenti analogici, documenti originali digitali, video, transazioni di dati), sia in relazione a strumenti e servizi fiduciari disciplinati da normative europee (firme elettroniche, sigilli, marche temporali). Manca tuttavia un regolamento unico europeo sulla conservazione a lungo termine e ogni Stato membro ha le proprie regole. Tra questi, Italia e Slovenia hanno un eccellente percorso di accreditamento di servizi di conservazione digitale, basato su audit periodici da parte dell'Agenzia per l'Italia Digitale e dell' Arhiv Republike Slovenije, che verificano requisiti di qualità e sicurezza, la presenza di personale qualificato, l'affidabilità dei prestatori di servizi e il rispetto di norme e standard.

Dokumenti, procesi, transakcije: evropska digitalna (r)evolucija

\section{IZVLE ČEK}

Digitalna arhivska znanost se v Evropi razvija glede na "predmete", ki jih moramo ohraniti (slikovne kopije izvirnih dokumentov, ročno-digitalnih dokumentov, videoposnetkov, podatkovnih transakcij) ter glede na orodja in zaupanja vredne storitve, ki jih ureja zakonodaja EU (elektronski podpisi, pečati, časovni žigi). Nimamo pa vseevropske ureditev za dolgoročno hrambo. Vsaka država članica to storitev izvaja z nacionalnimi pravili. Italija in Slovenija imata odličen postopek akreditacije storitev na podlagi redne revizije Agenzia per l'Italia Digitale in Arhiva Republike Slovenije, kar potrjuje visoko raven kakovosti in varnosti, prisotnost usposobljenega osebja, zanesljivost zanesljivega ponudnika storitev in skladnost $\mathrm{z}$ normami in standardi. 
Digital archival science has strongly evolved in the last ten years: compared to the past, today the science is characterised by a more multidisciplinary approach (traditional archival science, process analysis, ICT law, forensic approach).

In the past, a typical digital archival project consisted in scanning analogical documents. These kind of projects, carried on by transportable scanner yards, targeted librarian heritage, manuscripts and items of great historical value to guarantee the possibilities of diffusion and access over time (this has been done, for exemple, in the DigitaVaticana project of the Apostolic Vatican Library and the recent collaboration with the University Library of Heidelberg to digitize the collection of the ancient Palatine Library).

In a second phase, less prestigious but still extremely useful projects were focused on tax-relevant documents belonging to national and local government administrations, with the goal of creating image-copies of the original documents, then discarding paper-masters.

More recently, digital archival science has changed the point of view, approaching the digitial reengineering of processes, with the goal to produce documents that are digital by default ('born digital'). In this case a record is created, managed, signed, shared and preserved only in a digital environment: a record's life-cycle becomes completely digital and paperless.

A key concept spread out: 'digital first'.

In other words, we need to build a 'digital citizenship' through the evolutione from a traditional fruition of services to citizens and businesses, to a new formula directed to the growth of a 'digital culture'.

By European Digital Agenda 20201 administrations and public institutions in the UE must be efficient, inclusive, and able to provide end-to-end digital public services, customized and intuitive for all: the use of technologies today is a Right, and this obviously creates an influence on records management.

New and innovative trusted tools and services are needed to make such processes a concrete reality: 'Trust service', that is an electronic service which consists of:

- the creation, verification, and validation of electronic signatures, electronic seals or electronic time stamps, electronic registered delivery services and certificates related to those services, or

- the creation, verification and validation of certificates for website authentication; or

- the preservation of electronic signatures, seals or certificates related to those services.

In the EU, two groundbreaking Regulations help to achieve trustworthy and secure record management among member states: eIDAS (electronic IDentification Authentication and Signature) and GDPR (General Data Protection Regulation).

At first we have eIDAS - Regulation No 910/2014 of the European Parliament and of the Council, of 23 July 2014, on electronic identification and trust services for electronic transactions in the internal market and repealing the Directive 1999/93/EC.

The aim of eIDAS is to enhance 'trust' in electronic transactions in the internal market by providing a common foundation for secure electronic interaction between citizens, businesses and public authorities, thereby increasing the effectiveness of public and private online services, electronic business and electronic commerce in the European Union.

1. The Digital Agenda presented by the European Commission forms one of the seven pillars of the Europe 2020 Strategy which sets objectives for the growth of the European Union (EU) by 2020. The Digital Agenda proposes to better exploit the potential of Information and Communication Technologies (ICTs) in order to foster innovation, economic growth and progress. 
The main trust services are basic tools for records management:

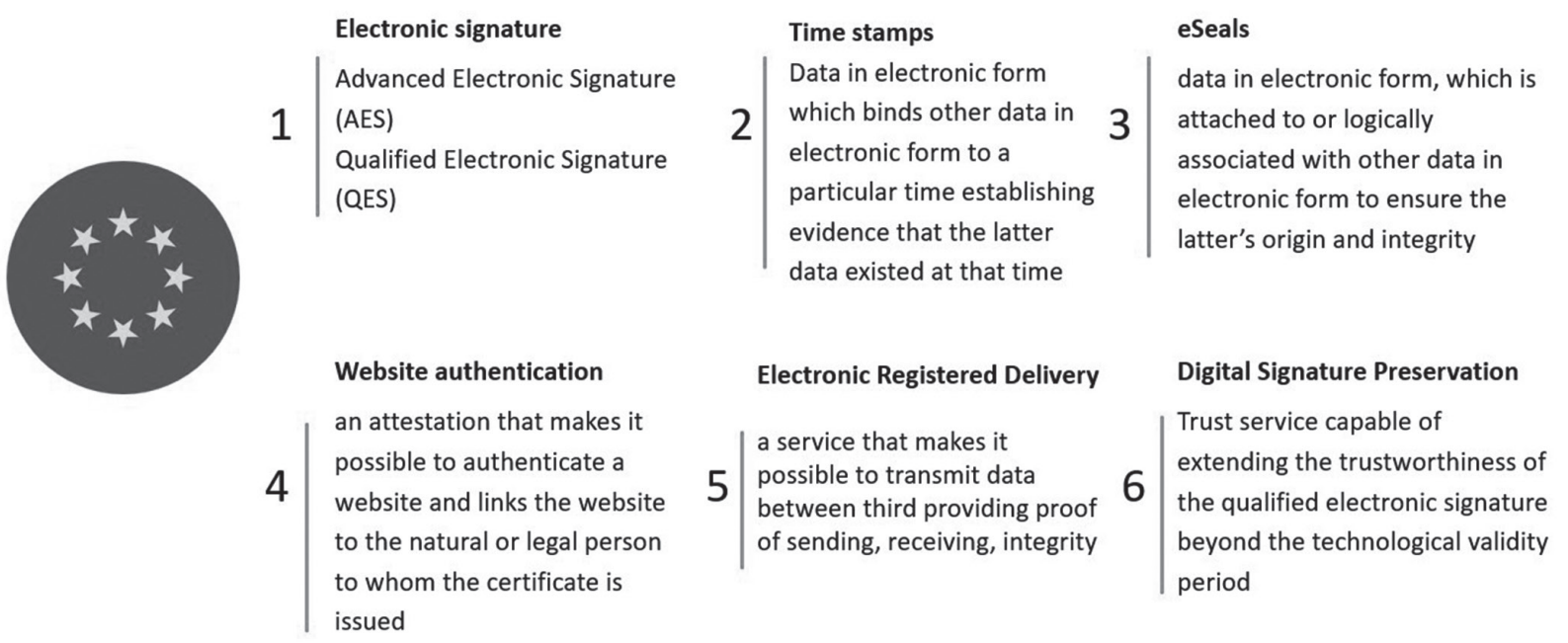

Only qualified electronic signatures enrolled by a trust service provider shall have legal effects equivalent to a handwritten signature. This kind of signature, based on a qualified certificate issued in one Member State, shall be recognised as a qualified electronic signature in all other Member States.

It is of primary importance to improve the European digital market and assure mutual recognition of certificates across all of the EU countries by removing existing differences among digital certificates enrolled by the trust service providers within the EU. This is crucial in order to build the necessary European trust on digital signatures and digital transactions.

In compliance with these rules, in the banking or insurance sector for example, the process of client identification, contract signing, and the connected liabilities and obligations could be outsourced to a Trust Service Provider (TSP) located in any of the EU countries.

A TSP manages the threats posed to security of the trust services they provide by adopting cutting-edge technologies and appropriate organizational measures aimed at preventing the risk and minimizing the impact of security incidents.

As part of those organizational measures, when issuing a qualified certificate for a trust service, a TSP verifies by appropriate means and in compliance with national law the identity and, if applicable, any specific attributes of the natural or juridical person to whom the qualified certificate is issued.

The information is verified by a TSP either directly with its staff or by relying on a third part of its RA (Registration Authority) network:

- by the physical presence of the natural person or of an authorised representative of the legal person; or

- remotely, using reliable electronic identification means.

An example of remote identification is the video-conference identification tool that permits to a Trust Service Provider as InfoCert to identify the customers in a trustworthy and reliable manner requiring only a webcam, a browser and an internet connection. Other examples are in the financial and insurace sectors, where AML regulations set up strict requirements for the identification of prospects, and this identities can be leveraged by a TSP to issue signature certificates.

The other main regulatory reference in the EU is the GDPR (General Data Protection Regulation), 2016/679 of the European Parliament and of the Council of 27 April 2016 on the protection of natural persons with regard to the processing of personal data and on the free movement of such data, and repealing the Directive 95/46/EC. The GDPR regulates the processing by an individual, a company or an organisation of personal data relating to individuals in the EU, and it has introduced basic princi- 
ples such as Accountability, Data Inventory, Vulnerability Assessment, Data protection by design and by default, Lawfulness of processing and Consent management.

Among the key principles in the GDPR are data minimisation and storage limitation. Personal data should be adequate, relevant and limited to what is necessary for the purposes for which they are processed. This requires, in particular, ensuring that the period for which the personal data are stored is strictly limited to the shortest time possible. Personal data should be processed only if the purpose of the processing could not be reasonably fulfilled by other means. In order to ensure that the personal data are not kept longer than necessary, time limits should be established by the controller for erasure or for a periodic review. Every reasonable step should be taken to ensure that personal data which are inaccurate are rectified or deleted. Personal data should be processed in a manner that ensures adequate security and confidentiality, including - but not limiting to - measures to prevent unauthorised access to or use of the data, and access to the equipment used for the processing (Whereas n. 39 GDPR).

In this context, it is important to emphasise that in regards to 'appraisal and disposal timeframe', Archival Science has a considerable experience.

With eIDAS and the GDPR we have a secure, trustworthy and pan-European framework to share and circulate data, records and documents: this creates a level playing field where the digital transformation trends that are naturally investing every sector, can be easily guided in the direction of the protection of the citizens, consumers, Public Authorities and businesses.

Digital Archival Science is directly impacted with almost two issues: how to preserve on time electronic documents that have a new different form factor, and how to preserve the memory if it is not anymore based on documents.

Let's look to an real example of 'paperless process' in the banking sector, as the remote customer onboarding: many banks are, in fact, adopting new processes of remote digital customer identification and signature of contracts ${ }^{2}$. In this case, it is really important to guarantee that the customers are who they claim to be or, in other words, their electronic identity.

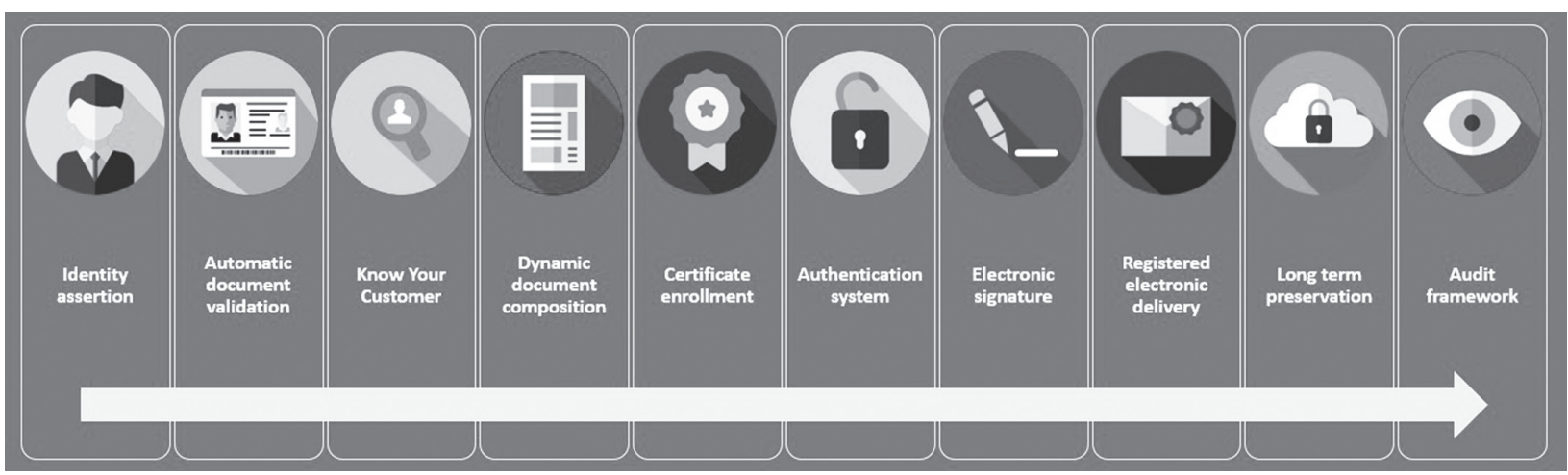

The different steps of the process create different 'objects' that shall be preserved (for a legal requirement and/or for a risk-management need). The objects are complex: a videostream of the identification, PDF contracts with multiple customer's electronic signature, identity documents and assertions, the trace of the willingness to accept specific and binding clauses or to read information documents, and so on.

This 'objects' are, according to eIDAS, 'electronic document' that is any content stored in electronic form, in particular text or sound, visual or audiovisual recording.

Still, the archival service's goals are the same as always: readability, integrity, durability, availability.

In detail, the key issues are:

2. The remote onboarding use case can be enabled by InfoCert Trusted Onboarding Platform (TOP), a patented solution that enables an easy and smart integration of identification and e-signature solutions within existing banking platforms. 
- the period for which the personal data will be stored, and the criteria used to determine that period

- obsolescence of formats

- storage media degradation

- data protection

- removal of application support

- retrieval information

- quickness in finding the documents and connected information.

Despite this, even if all these issues are becoming increasingly challenging over time, a Digital Archivist can anyway rely on his/her expertise in managing documents and so reduce this problems in a known frame.

But today Digital Archivists are facing a further great challenge: the disappearance of the concept of document.

In the Intenet of Things paradigma, we have billions of transactions flowing between machines, humans, intelligent agents, legal entities that produces memories and legal effects.

According to Forbes, experts predict that there may be as many as 200 billion IoT devices in operation by 2020. In other words, between 2005 and 2013, the amount of data in the world raised from 132 exabytes to 4.4 zettabytes (a 33 -fold increase).

The world of IoT is projected to grow 10 times more by 2020. Moving toward a world where virtually everything is converted to a data source raises additional important question: Where will all the data go? Whether organizations opt for on-premises or cloud-based storage solutions, it's crucial that stored data be accessible or it won't lead to the results possible with IoT.

Indeed, data are often defined as the 'new oil'?.

For instance, wearable devices for the remote control of biological parameters used in health monitoring, smart cars that communicate with road signage and insurance companies, building automation, smart cities, smart agri-food, precision farming.

Legally remarkable decisions are taken on the base of online connected objects and, sometimes, the objects themselves take decisions.

This is, therefore, an accountability problem, but also a data preservation issue, and digital archivists must be involved in this revolution.

We believe that Digital Archival Science has not yet fully considered the Internet of Things and his moral and legislative implications. In this case what is the 'object' that has to be preserved? When a 'transaction' becomes whorty to be eligible for preservation? Who is the Producer of the preserved object? A machine? A human? A Legal Entity?

Unfortunately, nowadays eIDAS does not discipline preservation services when they are used in contexts other than the extention of the validity status of an electronic signature and providing a proof of existence of a document in a given date and time. Lacking a EU-wide regulation, each member state disciplines this service with national rules.

Some countries, such as the UK, have little regulation (only standards and guidelines), while other countries, such as Italy or Slovenia, are highly regulated (defining audit, accreditation, and certification processes, as well as detailed mandatory requirements).

To cope with the new challenges of the digitally transformed world, we believe that a new common European framework for digital data and document long-term preservation should be established, taking inspiration from the experiences of Member States that already set up national regulatory frameworks, as are Italy and Slovenia.

3. The concept is usually credited to Clive Humby, the British mathematician who established Tesco's Clubcard loyalty program. Humby highlighted the fact that, although inherently valuable, data needs processing, just as oil needs refining before its true value can be unlocked. 
In Italy, the framework is based on the OAIS standard (Open Archive Information System, developed by the Consultative Committee for Space Data Systems - CCSDS - ISO 14721:2012), enhanced by an Italian standard (UNI 11386:2010 SInCRO - the acronym stand for interoperability in a preservation system and recovery of digital objects' in Italian) that outline the basic rules for long term preservation of electronic documents with legal value.

These rules cover:

- The concept of 'information package': a conceptual container composed of optional Content Information and optional associated Preservation Description Information. Associated with this Information Package is Packaging Information used to delimit and identify the Content Information and Package Description information used to facilitate searches for the Content Information.

- The acquisition and the verification on the part of the Preservation System of the Submission Information Package (SIP), that is an Information Package delivered by the Producer.

- The transformation of a SIP in an AIP (Archival Information Package), namely an Information Package, consisting of the Content Information and the associated Preservation Description Information.

- The research, the retrieval and the show of Dissemination Information Package (DIP), that is an Information Package, derived from one or more AIPs, received by the Consumer in response to a request.

- The generation, even in the automatic mode, of a Receipt for every SIP, uniquely identified by the system, and with a Time Stamp and the Preservation Manager's electronic signature.

- Specific file formats (PDF, XML, TIFF...);

- Specific document types (invoices, contracts, register...);

- Specific metadata (date, subject, producer...).

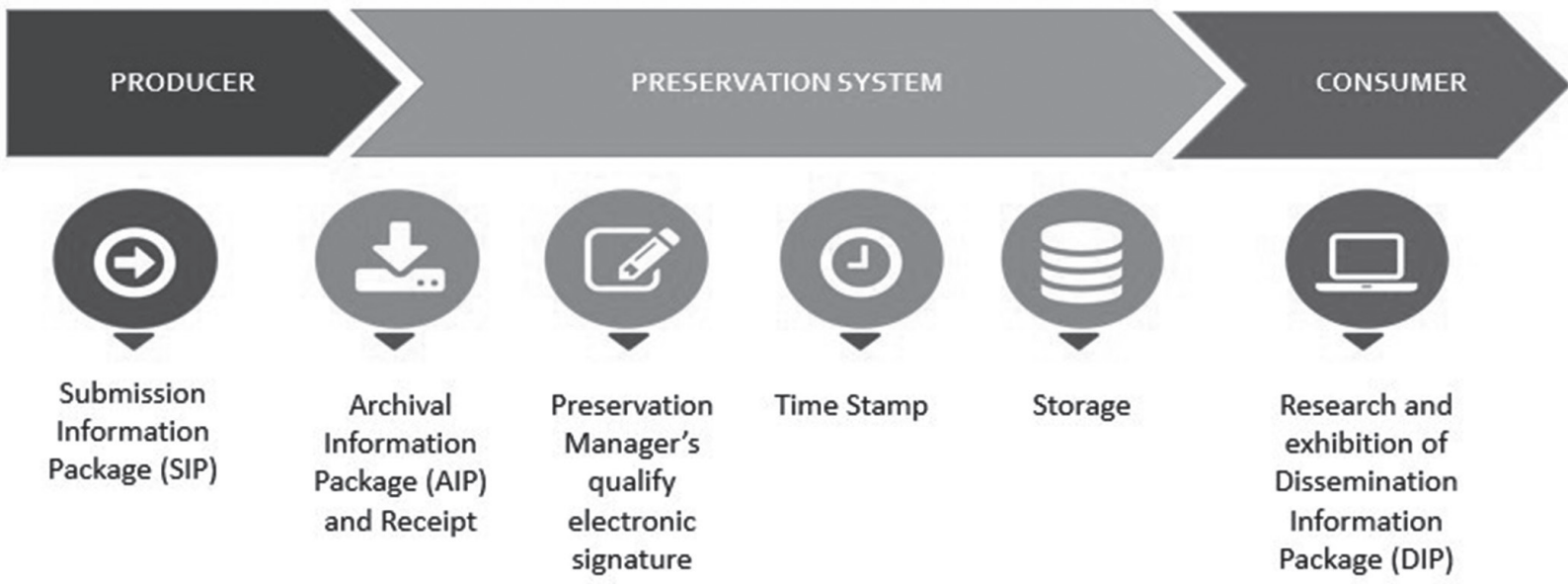

In Italy there is also a Services Accreditation and Certification procedure, comparable to the one required for eIDAS Qualified Trust Services, and managed by AgID, a Government Agency operating as a Supervisory Body.

AgID attests quality and high security level of the tenders, it watches over on the accredited activities and sets the mandatory requirements for Accreditation.

InfoCert's preservation service is accredited in Italy since 2014, and on its way to be accredited in other countries following accreditation procedures similar to the ones adopted in Italy, with the goal of building an International Preservation Service. 
A Preservation Accredited Service shall demonstrate:

- the compliance with the technical requirements set by the supervisory body;

- organizational, technical and financial reliability;

- qualified and trained staff, including a digital archivist, which has the goal of defining metadata, archival description, retrival policy, integrity and readability checks, to cooperate with the Producer and the Ministry for Cultural Heritage;

- the adoption of appropriate and sufficient measures to data protection and retrival information;

- the prevention of technological obsolescence;

- the existence of a Preservation Practice Statement, that exactly details information such as organization, managers and staff, policies, rules, processes, architecture and infrastructure, security mesures. provided.

Moreover, AgID has provided a specific checklist including 73 requirements and evidences to be

The Slovenian main Code ruling over digital archiving is ZVDAGA - Zakon o varstvu dokumentarnega in arhivskega gradiva ter arhivih, Ur. L. RS, št. 30/2006, 24/2014 in 51/2014.

It covers general principles of accessibility, usability, integrity, authenticity and protection of cultural heritage, different media (paper, scan, born digital), 'reliable conversion process' (zanesljive pretvorbe) long-term preservation.

In addition, the Protection of Documents and Archives and Archival Institutions Act, 2014 (PDAAIA) gives further details on the the protection of documents and archives, on the validity and evidentiary value of such materials, on the protection of public and private archives as cultural heritage, on the access to archives in archival institutions and on the conditions for using archives, and also on the reliable conversion of captured material into digital form for long-term preservation.

The Slovenian Supervisory Body is the National Archives (Arhiv Republike Slovenije), that:

- certifies systems (certifikacija sistemov) for public archives,

- holds public lists of suppliers companies and of confirmed internal rules (Register Ponudnikov opreme in storitev ter Register potrjenih notranjih pravil),

- gives permission for disposal (uničenje) documentary material,

- does inspections,

- gives sanctions.

In Slovenia, as well as in Italy, there is a specific checklist with requirements, in order to demonstrate an high-level of quality and security (based on ISO 27001 Information Security Management and on ISO 9001 Quality Management).

The certification is voluntary and open to all the providers of equipment (hardware and software) and the suppliers of archival services, Slovenian or foreigner, in compliance with ZVDAGA and UE Regulations. It is mandatory for the suppliers to central and local government agencies and authorities.

The public list of suppliers, Register Elektronske Hrambe, is focused in particolar on electronic equipments, systems, infrastructures, internal rules and machines, it is organized in five sections and it contains profiles and addresses of all suppliers.

Italy and Slovenia build on similar standards, procedures and regulatory frameworks for digital archiving, and share great similarities that can be leveraged to produce synergies and a parallel, efficient improvement in the archival practices in the two countries, both on the practical and regulatory side.

In conclusion, we believe that Digital Archivist Science is facing - and will face more and more in the future - big challenges that requires a real ( $\mathrm{r}$ )evolution: a complete re-thinking of the idea of the archivist competences and, maybe, even of the definition of 'document' that has to be preserved.

At the same time, a Digital Archivist that operates in the intersection between European Regulations, evolution trends, national expertise in digital preservation systems, public and business needs has a 
real chance to become a unique ally for every organization and Authority to cope with the new needs posed by an evolving world.

Such Archivist will be really working on daily basis to realize the Digital Archival Science mission: consign to the future generations the memory or our time, for the first time in history without relying on physical support but melting technology, processes and people's behaviours.

\section{References}

Digita Vaticana Onlus is a non-profit organization founded in 2013 to promote the conversion of the 80.000 Vatican Library manuscripts into digital format. http://www.digitavaticana.org/.

Bibliotheca Palatina: Ein einmaliger Bücherschatz ist digital wiedervereint. https://www.uni-heidelberg.de/presse/news2018/pm20180209_bibliotheca-palatina-ein-einmaliger-buecherschatz-ist-digital-wiedervereint.html.

May 2, 2017 - The Future Is Data-Driven, But IoT Has Its Challenges, www.forbes.com.

The European Commission Digital Agenda 2020, https://ec.europa.eu/digital-single-market/en/europe-2020-strategy.

eIDAS - REGULATION (EU) No 910/2014 OF THE EUROPEAN PARLIAMENT AND OF THE COUNCIL of 23 July 2014 on electronic identification and trust services for electronic transactions in the internal market https://eur-lex.europa.eu/legal-content/IT/TXT/?uri=celex\%3A32014R0910.

GDPR - REGULATION (EU) 2016/679 OF THE EUROPEAN PARLIAMENT AND OF THE COUNCIL of 27 April 2016 on the protection of natural persons with regard to the processing of personal data and on the free movement of such data, and repealing Directive 95/46/EC (General Data Protection Regulation) https://eur-lex. europa.eu/legal-content/en/ALL/?uri=CELEX:32016R0679.

\section{Italian Archiving Technical Rules}

Government Decree December 3, 2013, https://www.agid.gov.it/sites/default/files/repository_files/leggi_decreti_direttive/dpcm_3-12-2013_conservazione.pdf.

AgID - Agenzia per l'Italia digitale - Italian Government Agency operating as a Supervisory Body, https://www. agid.gov.it/it, https://www.agid.gov.it/it/piattaforme/conservazione

\section{Accreditation and Supervision Rules}

CIRCOLARE N. 65 del 10 aprile 2014, https://www.agid.gov.it/sites/default/files/repository_files/circolari/circolare_accreditamento_conservatori_n_65_10-04-2014.pdf.

Job Profiles, https://www.agid.gov.it/sites/default/files/repository_files/documentazione/profili_professionali_ per_la_conservazione.pdf.

The Archives of the Republic of Slovenia - Ministry of Culture, http://www.arhiv.gov.si/si/.

\section{Slovenian Archiving Technical Rules}

- PROTECTION OF DOCUMENTS AND ARCHIVES AND ARCHIVAL INSTITUTIONS ACT.

Uradni list RS 30/2006 z dne 23.3.2006 ZAKON O VARSTVU DOKUMENTARNEGA IN ARHIVSKEGA GRADIVA TER ARHIVIH (ZVDAGA), http://www.arhiv.gov.si/fileadmin/arhiv.gov.si/pageuploads/zakonodaja/zvdaga.pdf.

- Številka: 382-14/2006/24 - KONTROLNI SEZNAM za potrjevanje notranjih pravil za zajem in hrambo dokumentarnega gradiva $v$ digitalni obliki, preverjanje njihovega izvajanja ter preverjanje izpolnjevanja pogojev za pridobitev akreditacije storitve v skladu z Zakonom o varstvu dokumentarnega in arhivskega gradiva ter arhivih.

/ZVDAGA/

http://www.arhiv.gov.si/fileadmin/arhiv.gov.si/pageuploads/E ARHIVI/obrazci/KSpNPpS_ver_2.0.pdf.

\section{Slovenian Public Registers}

http://www.arhiv.gov.si/si/javne_evidence/. 
http://reh.ars.gov.si/index.php?page=webInterface\&idDefinition $=1$.

Certifikacija: http://www.arhiv.gov.si/si/delovna_podrocja/hramba_dokumentarnega_gradiva_v_elektronski_ obliki/certifikacija/.

http://www.arhiv.gov.si/si/zakonodaja_in_dokumenti/:

- II. del: Enotne tehnološke zahteve za zajem in hrambo gradiva v digitalni obliki: http://www.arhiv.gov.si/fileadmin/arhiv.gov.si/pageuploads/E-ARHIVI/ETZ_2_1/ETZ_-_II._del_razlicica_2.1_-_koncna.doc.pdf.

- III. del: Dodatne enotne tehnološke zahteve za ponudnike, strojno in programsko opremo ter storitve: http:// www.arhiv.gov.si/fileadmin/arhiv.gov.si/pageuploads/E-ARHIVI/ETZ_2_1/ETZ_2.1_III.del_k.pdf.

\section{SUMMARY}

Digital archival science has evolved in the last ten years: in the past, a typical digital archival project consisted in scanning analogical documents, but recently the approach is changed toward the complete reenginering of the processes, with the goal to produce documents that are digital by default ('born digital'). In this new scenario, innovative trusted tools and services are needed. In the EU, two groundbreaking Regulations help to achieve trustworthy and secure record management among member states: eIDAS (electronic IDentification Authentication and Signature) and GDPR (General Data Protection Regulation). This creates a level playing field where the digital transformation trends that are naturally investing every sector, can be easily guided in the direction of the protection of the citizens, consumers, Public Authorities and businesses. Digital Archival Science is directly impacted with almost two issues: how to preserve on time electronic documents that have a new different form factor, and how to preserve the memory if it is not anymore based on documents. In addition, nowadays Digital Archivists are facing a further great challenge: the disappearance of the concept of document. In the Intenet of Things (IoT) paradigma, we have billions of transactions flowing between machines, humans, intelligent agents, legal entities that produces memories and legal effects. We believe that Digital Archival Science has not yet fully considered moral and legislative implications of IoT. To cope with the new challenges of the digitally transformed world, a new common European framework for digital data and document long-term preservation should be established, taking inspiration from the experiences of Member States that already set up national regulatory frameworks, as are Italy and Slovenia (they have a excellent Services Accreditation Procedure, with a specific checklist, in order to demonstrate an high-level of quality and security). In conclusion, we believe that Digital Archivist Science is facing - and will face more and more in the future - big challenges that requires a real ( $\mathrm{r}$ )evolution: a complete re-thinking of the idea of the archivist competences and, maybe, even of the definition of 'document' that has to be preserved. At the same time, a Digital Archivist has a real chance to become a unique ally for every organization and Authority to cope with the new needs posed by an evolving world.

Typology: 1.02 Review article

Submission date: 06.07.2018

Acceptance date: 08.08.2018 